\title{
STRATEGI UNTUK MEMUTUS RANTAI INFEKSI BESERTA UPAYA MENCEGAH HAZARD FISIKA DAN KIMIA PADA PERAWAT DI RUMAH SAKIT
}

\author{
Ananda Muthia Bahri Hasibuan \\ anandamuthiag3@gmail.com
}

\section{Latar Belakang}

Rumah sakit merupakan tempat kerja yang berpotensi tinggi terhadap terjadinya kecelakaan kerja. Adanya bahan mudah terbakar, gas medis, radiasi pengion dan bahan kimia membutuhkan perhatian serius terhadap keselamatan pasien, staf dan umum (Sarastuti, 2016).

Mutu pelayanan kesehatan khususnya pelayanan keperawatan di rumah sakit dapat dinilai dari berbagai indikator salah satunya penilaian terhadap infeksi, hazard fisik maupun kimia. Infeksi silang yang berasal dari rumah sakit dan fasilitas pelayanan kesehatan yang lain disebut healthcare associated infection/HAIs atau infeksi nosokomial (kemenkes, 2011). Infeksi ini biasanya datang dari tubuh pasien, kontak dengan petugas kesehatan, peralatan medis yang terkontaminasi dari lingkungan. (Saifuddin dkk, 2004).

Infeksi akibat layanan kesehatan atau Healthcare Associated Infections(HAIs) adalah infeksi yang terjadi pada pasien selama perawatan di rumah sakit atau fasilitas kesehatan lainnya. Infeksi tersebut tidak ditemukan atau tidak sedang berinkubasi pada saat pasien masuk. Termasuk dalam definisi ini adalah infeksi yang didapat di rumah sakit namun baru bermanifestasi setelah pasien keluar. Selain pada pasien, HAIs dapat terjadi pada tenaga kesehatan dan staf rumah sakit. (WHO2010).

Infeksi yang sering terjadi dirumah sakit adalah infeksi plebitis, ILO dan decubitis (Nugraheni, 2011). Sementara standar indikator infeksi nosokomial pada pasien rawat inap adalah 1,5\% (Depkes RI, 2008). Hal ini merupakan bahwa kejadian infeksi dirumah sakit masih diatas standar yang telah ditetapkan.

Kejadian infeksi nosokomial merupakan masalah yang sangat penting diseluruh dunia, karena perawatan yang lama dan membutuhkan dana yang cukup besar selama perawatan dan berkontribusi terhadap meningkatkan angka kesakitan dan kematian. Peningkatan angka kejadian infeksi nosokomial menunjukkan bahwa kejadian infeksi nosokomial masih cukup banyak dan perlu antisipasi supaya kajadian infeksi berkurang dan bahkan tidak terjadi kembali.

Infeksi nosokomial terjadi karena adanya transisi mikroba pathogen yang bersumber dari lingkungan rumah sakit dan perangkatnya. Akibat lainnya yang juga cukup merugikan adalah hari rawat penderita bertambah, beban biaya menjadi semakin besar, serta merupakan bukti bahwa manajemen pelayanan medis rumah sakit kurang membantu. 
Pencegahan dan pengendalian infeksi nosokomial di rumah sakit sangat penting dilakukan karena kejadian infeksi nosokomial menggambarkan mutu pelayanan rumah sakit. Resiko terjadinya infeksi di rumah sakit dapat diminimalkan dengan kegiatan perencanaan, pelaksanaan, pembinaan, pendidikan dan pelatihan, monitoring dan evaluasi.

Penularan infeksi yang sering terjadi di lingkungan pelayanan rumah sakit sangat berisiko terpapar ke tenaga kesehatan, pasien, pengunjung bahkan karyawan. Pelayanan kesehatan yang diberikan ke pasien harus didukung oleh sumber daya manusia yang berkualitas untuk mencapai pelayanan yang prima dan optimal.

Infeksi nosokomial dapat menular jika dalam penanganan perawat terhadap pasien tidak steril. Salah satu cara untuk mencegah penularan tersebut adalah dengan memakai alat pelindung diri (sarung tangan dan masker) pada perawat saat memberikan tindakan terhadap pasien.

\section{METODE}

Melakukan obeservasi yang didasarkan atas literatur penelitian. Dijelaskan secara deskriptif. Berdasarkan literatur tersebut akan disesuaikan dengan judul jurnal ini strategi untuk memutus rantai infeksi dan mencegah hazard fisik radiasi beserta upaya mencegah hazard kimia para perawat di rumah sakit. Metode yang saya gunakan yaitu dengan menggunakan metode literatur review dengan pendekatan jurnal, tesis, buku dan ebook untuk mendapatkan data yang akurat mengenai perencanaan keperawatan dalam keluarga. Adapun jurnal atau artikel dan e-book yang digunakan pada literatur review adalah jurnal dan e-book yang didapatkan dengan menggunakan google scholar .

\section{HASIL}

Pencegahan dan pengendalian infeksi merupakan tantangan terbesar dalam tatanan pelayanan kesehatan, dan peningkatan biaya untuk mengatasi infeksi yang berhubungan dengan pelayanan kesehatan merupakan keprihatinan besar bagi pasien maupun para professional pelayanan kesehatan. Infeksi biasanya dijumpai dalam semua bentuk pelayanan kesehatan termasuk infeksi saluran kemih. Infeksi biasanya dijumpai dalam semua bentuk pelayanan kesehatan termasuk infeksi saluran kemih, infeksi pada aliran darah (blood stream infection) dan pneumonia (seringkali dihubungkan dengan ventilasi mekanis).

Infeksi nosokomial diperoleh pasien saat dilakukan perawatan dirumah sakit, tanpa adanya tanda-tanda infeksi sebelumnya, biasanya terjadi dalam waktu 3x24 jam sesudah masuk kuman. Jenis infeksi yang sering di derita oleh pasien adalah Infeksi Luka Operasi, Infeksi Saluran Kemih, dan Infeksi Saluran Pernapasan bawah (Pneumonia).

Terdapat beberapa tindakan pencegahan infeksi nosokomial yaitu melakukan cuci tangan untuk menghindari infeksi silang, memakai sarung tangan bila kontak dengan cairan, 
darah dan bahan terkontaminasi, menggunakan alat pelindung diri seperti memakai apron, masker, pelindung mata, manajemen benda tajam secara benar dan menjaga sanitasi lingkungan.

Potensi bahaya fisika yang teridentifikasi yaitu pencahayaan, dengan melakukan perawatan terhadap pasien pada siang hari. Dapat terjadi resiko bahaya kelelahan mata, keluhan pegal dan efisiensi kerja menurun. Dari peraturan Kepmenkes RI No 1204/MENKES/SK/X/2004 tentang persyaratan kesehatan lingkungan rumah sakit, pencahayaan ruang pasien 100-200 lux dengan warna cahaya sedang.

Strategi pengendalian bahasa fisika yaitu aktivitas kerja melakukan perawatan terhadap pasien pada siang hari adalah memperoleh penerangan yang cukup dan sesuai. Untuk pengendalian risiko yaitu gunakan pencahayaan yang baik agar penglihatan bisa melihat dengan jelas pada objek, untuk menghindari kemungkinan terjadinya penyakit akibat kerja dan kecelakaan akibat kerja.

Potensi bahaya kimia yang teridentifikasi yaitu disinfektan, dengan melakukan pembersihan ruangan. Dapat terjadi resiko bahaya keracunan, cedera mata dan infeksi. Dari Undang-undang No 1 Tahun 1970 tentang keselamatan kerja, BAB III Pasal 3 ayat 1 memelihara kebersihan, kesehatan dan ketertiban. Serta Permenkes No 66 Tahun 2016 tentang Keselamatan Dan Kesehatan Kerja Rumah Sakit BAB III Standar Keselamatan Dan Kesehatan Kerja,bahwa bahaya kimia yaitu disinfektan berada di semua area dan pekerja yang paling beresiko yaitu petugas kebersihan dan perawat.

Strategi pengendalian bahaya kimia (disinfektan) yaitu aktivitas kerja melakukan perawatan terhadap pasien pada siang hari adalah harus memperhatikan tanda-tanda perigatan yang ada di area kerja untuk mengantisipasi adanya bahaya pada bahan kimia yang bersedia diruangan tersebut dan perhatikan penggunaan bahan kimia sesuai prosedur.

\section{PEMBAHASAN}

Menurut Peraturan Menteri Kesehatan Republik Indonesia, Nomor 1691/Menkes/per/VIII/2011. Keselamatan pasien rumah sakit adalah sistem dimana rumah sakit membuat asuhan pasien lebih aman. Sistem tersebut meliputi pengkajian resiko, identifikasi dan pengelolaan hal yang berhubungan dengan resiko pasien, pelaporan dan analisis insiden dan pencegahan penyakit infeksi, kemampuan belajar dari insiden dan tindak lanjutnya serta implementasi solusi untuk meminimalkan timbulnya resiko. Sistem tersebut diharapkan dapat mencegah timbulnya cidera yang disebabkan oleh kesalahan akibat melaksanakan suatu tindakan atau tindakan yang seharusnya dilakukan.

Infeksi merupakan salah satu masalah kesehatan di dunia, termasuk Indonesia. Ditinjau dari asal atau didapatnya infeksi dapat berasal dari komunitas (community acquired infection) atau berasal dari lingkungan rumah sakit (Hospital acquired infection) yang sebelumnya dikenal dengan istilah infeksi nosokomial. Dengan berkembangnya sistem pelayanan kesehatan khususnya dalam bidang perawatan pasien, sekarang perawatan tidak 
hanya di rumah sakit saja, melainkan juga di fasilitas pelayanan kesehatan lainnya, bahkan perawatan di rumah (home care). Tindakan medis yang dilakukan oleh tenaga kesehatan yang dimaksudkan untuk tujuan perawatan atau penyembuhan pasien, bila dilakukan tidak sesuai prosedur berpotensi untuk menularkan penyakit infeksi, baik bagi pasien (yang lain) atau bahkan pada petugas kesehatan itu sendiri.

Rantai Penularan Untuk melakukan tindakan pencegahan dan pengendalian infeksi perlu mengetahui rantai penularan. Apabila satu mata rantai dihilangkan atau dirusak, maka infeksi dapat dicegah atau dihentikan. Komponen yang diperlukan sehingga terjadi penularan tersebut adalah:
a. Agen infeksi (infectious agent).
b. Reservoir atau tempat dimana agen infeksi dapat hidup, tumbuh, berkembang biak dan siap ditularkan kepada orang.
c. Pintu keluar (portal of exit).
d. Pintu masuk (portal of entry).
e. Pejamu (host) yang suseptibel.

Pengendalian infeksi nosokomial adalah kegiatan yang meliputi perencanaan, pelaksanaan dan pengawasan serta pembinaan dalam upaya menurunkan angka kejadian infeksi di rumah sakit. Proses terjadinya infeksi bergantung kepada interaksi antara suseptibilitas pejamu, agen infeksi (pathogenesis, virulensi dan dosis) serta cara penularan. Identifikasi faktor risiko pada pejamu dan pengendalian terhadap infeksi tertentu dapat mengurangi insiden terjadinya infeksi nosokomial/HAIs, baik pada pasien ataupun pada petugas kesehatan.

Pencegahan dan Pengendalian infeksi menjadi bagian penting dalam upaya meningkatkan mutu pelayanan medis dan asuhan keperawatan di Puskesmas yang berfokus pada keselamatan pasien, petugas dan lingkungan puskesmas. Kinerja PPI dicapai melalui keterlibatan aktif semua petugas Puskesmas, mulai dari jajaran manajemen, dokter, perawat, paramedis, pekarya, petugas kebersihan, sampai dengan petugas parkir dan satpam maupun seluruh masyarakat di puskesmas seperti pengunjung, mitra kerja puskesmas (Bank, asuransi, rekanan penyedia barang, dll). Kegiatan PPI harus dilakukan secara tepat di semua bagian/area di Puskesmas, mencakup seluruh masyarakat puskesmas dengan menggunakan prosedur dan petunjuk pelaksanaan yang ditetapkan oleh Puskesmas. Upaya pokok PPI mendasarkan pada upaya memutus rantai penularan infeksi berfokus pada Kewaspadaan Standar (Standart Precautions) yang merupakan gabungan Kewaspadaan Universal (Universal Precautions) dan BSI (Body Substance Isolation), serta Kewaspadaan Isolasi berdasarkan transmisi penyakit.

Pencegahan dan pengendalian infeksi yaitu dengan cara proses terjadinya infeksi bergantung kepada interaksi antara suseptibilitas pejamu, agen infeksi (patogenitas, virulensi dan dosis) serta cara penularan. Identifikasi faktor risiko pada pejamu dan pengendalian terhadap infeksi tertentu dapat mengurangi insiden terjadinya infeksi (HAIs), baik pada pasien ataupun pada petugas kesehatan. 
Adapun strategi pencegahan dan pengendalian infeksi terdiri dari:

a. Peningkatan daya tahan pejamu. Daya tahan pejamu dapat meningkat dengan pemberian imunisasi aktif (contoh vaksinasi Hepatitis B), atau pemberian imunisasi pasif (imunoglobulin).

b. Inaktivasi agen penyebab infeksi. Inaktivasi agen infeksi dapat dilakukan dengan metode fisik maupun kimiawi. Contoh metode fisik adalah penasaran (Pasteurisasi atau Sterilisasi) dan termasuk makanan seperlunya. Metode kimiawi termasuk klorinasi air, desinfeksi.

c. Memutus rantai penularan. Hal ini merupaka cara yang paling mudah untuk mencegah penularan penyakit infeksi, tetapi hasilnya sangat bergantung kepada ketaatan petugas dalam melaksanakan prosedur yang telah ditetapkan.

d. Tindakan pencegahan paska pajanan (Post Exposure Prophylaxis/PEP) terhadap petugas kesehatan. Hal ini terutama berkaitan dengan pencegahan agen infeksi yang ditularkan melalui darah dan cairan tubuh lainnya, yang sering terjadi karena luka tusuk jarum bekas pakai atau pajanan lainnya. Penyakit yang perlu mendapat perhatian adalah hepatitis B, Hepatitis C dan HIV.

Penilaian risiko merupakan salah satu proses dari analisis risiko, penilaian risiko dalam penelitian ini menggunakan metode kualitatif yaitu dengan matrik risiko yang menggambarkan tingkat dari kemungkinan dan keparahan suatu kejadian yang dinyatakan dalam bentuk rentang dari risiko paling rendah sampai risiko tertinggi. Menurut standar AS/NZS 4360 kemungkinan (probability) diberi rentang antara suatu risiko yang jarang terjadi sampai dengan risiko yang dapat terjadi setiap saat. Untuk keparahan (consecuence) dikategorikan antara kejadian yang tidak menimbulkan cedera atau hanya kerugian kecil dan yang paling parah jika dapat menimbulkan kejadian fatal (meninggal dunia) atau kerusakan besar terhadap aset organisasi.

Potensi bahaya fisika yang teridentifikasi yaitu pencahayaan, dengan melakukan perawatan terhadap pasien pada siang hari. Dapat terjadi resiko bahaya kelelahan mata, keluhan pegal dan efisiensi kerja menurun. Dari peraturan Kepmenkes RI No 1204/MENKES/SK/X/2004 tentang persyaratan kesehatan lingkungan rumah sakit, pencahayaan ruang pasien 100-200 lux dengan warna cahaya sedang.

Bahaya fisika yang mungkin terjadi adalah paparan suhu tinggi ataupun rendah, kelembaban, radiasi, listrik, dan suara (Wigmore, 2009). Paparan ini sering terjadi pada proses produksi sediaan farmasi, karena mesin-mesin yang digunakan menggunakan listrik yang tinggi dan menghasilkan suara yang bising.

Bahaya fisika potensial seperti paparan bahan radioaktif. Strategi pengendalian dalam proses produksi adalah menggunakan kaca penahan dan APD yang digunakan sarung tangan, pakaian pelindung, dan pelindung mata. Selain itu bahaya fisika potensial lainnya terluka karena benda kaca yang pecah, penggunaan mesin dan alat. Strategi pengendalian dalam proses produksi adalah mengganti dengan bahan lain seperti plastik, penjagaan mesin, sistem 
interlock, dan desain area kerja dan APD yang digunakan pelindung mata, pakaian pelindung, dan juga sarung tangan

Upaya pengendalian bahaya fisika (pencahayaan) yaitu aktivitas kerja melakukan perawatan terhadap pasien pada siang hari adalah memperoleh penerangan yang cukup dan sesuai. Untuk pengendalian resiko yaitu gunakan pencahayaan yang baik agar penglihatan bisa melihat dengan jelas pada objek, untuk menghindari kemungkinan terjadinya penyakit akibat kerja dan kecelakaan akibat kerja.

Potensi bahaya kimia yang teridentifikasi yaitu disinfektan, dengan melakukan pembersihan ruangan. Dapat terjadi resiko bahaya keracunan, cedera mata dan infeksi. Dari Undang-undang No 1 Tahun 1970 tentang keselamatan kerja, BAB III Pasal 3 ayat 1 memelihara kebersihan, kesehatan dan ketertiban. Serta Permenkes No 66 Tahun 2016 tentang Keselamatan Dan Kesehatan Kerja Rumah Sakit BAB III Standar Keselamatan Dan Kesehatan Kerja,bahwa bahaya kimia yaitu disinfektan berada di semua area dan pekerja yang paling beresiko yaitu petugas kebersihan dan perawat.

Efek paparan kimia dapat berupa ruam kulit akut dan kesulitas bernafas hingga penyakit kronis seperti kanker, gangguan reproduksi, gangguan pencernaan, dan lain-lain (Hodgkinson and Prasher, 2006). Setiap kasus hipersensitivitas saat kerja yang disebabkan karena bahan baku zat aktif obat dapat menjadi informasi tambahan pada risiko kesehatan yang berhubungan dengan penggunaan regular obat dalam terapi (Milkovic, et al., 2007).

Bahaya kimia potensial seperti terpapar obat berbahaya saat proses formulasi, menangani tumpahan, penerimaan dan unpacking, pengemasan. Strategi pengendalian dari bahan kimia yaitu, Proses produksi nya adalah alat pencegah yang tepat saat membuat obat, area dan peralatan yang dibatasi dengan baik dan APD yang digunakan yaitu pelindung mata dan wajah, pakaian pelindung dan sarunng tangan. Masker berdasarkan penilaian risiko dibutuhkan saat menangani obat aerosol.

Upaya pengendalian bahaya Kimia (disinfektan) yaitu aktivitas kerja melakukan perawatan terhadap pasien pada siang hari adalah harus memperhatikan tanda-tanda peringatan yang ada di area kerja untuk mengantisipasi adanya bahaya pada bahan kimia yang tersedia diruangan tersebut dan perhatikan penggunaan bahan kimia sesuai prosedur.

\section{PENUTUP}

Berdasarkan dari jurnal yang saya buat dan sesuai dengan referensi yang saya cari dapat disimpulkan bahwa strategi pencegahan dan pengendalian infeksi terdiri dari:

a. Peningkatan daya tahan pejamu. Daya tahan pejamu dapat meningkat dengan pemberian imunisasi aktif (contoh vaksinasi Hepatitis B), atau pemberian imunisasi pasif (imunoglobulin).

b. Inaktivasi agen penyebab infeksi. Inaktivasi agen infeksi dapat dilakukan dengan metode fisik maupun kimiawi. Contoh metode fisik adalah penasaran (Pasteurisasi 
atau Sterilisasi) dan termasuk makanan seperlunya. Metode kimiawi termasuk klorinasi air, desinfeksi.

c. Memutus rantai penularan. Hal ini merupaka cara yang paling mudah untuk mencegah penularan penyakit infeksi, tetapi hasilnya sangat bergantung kepada ketaatan petugas dalam melaksanakan prosedur yang telah ditetapkan.

d. Tindakan pencegahan paska pajanan (Post Exposure Prophylaxis/PEP) terhadap petugas kesehatan. Hal ini terutama berkaitan dengan pencegahan agen infeksi yang ditularkan melalui darah dan cairan tubuh lainnya, yang sering terjadi karena luka tusuk jarum bekas pakai atau pajanan lainnya. Penyakit yang perlu mendapat perhatian adalah hepatitis B, Hepatitis C dan HIV.

Upaya pengendalian bahaya fisika (pencahayaan) yaitu aktivitas kerja melakukan perawatan terhadap pasien pada siang hari adalah memperoleh penerangan yang cukup dan sesuai. Untuk pengendalian resiko yaitu gunakan pencahayaan yang baik agar penglihatan bisa melihat dengan jelas pada objek, untuk menghindari kemungkinan terjadinya penyakit akibat kerja dan kecelakaan akibat kerja.

Upaya pengendalian bahaya Kimia (disinfektan) yaitu aktivitas kerja melakukan perawatan terhadap pasien pada siang hari adalah harus memperhatikan tanda-tanda peringatan yang ada di area kerja untuk mengantisipasi adanya bahaya pada bahan kimia yang tersedia diruangan tersebut dan perhatikan penggunaan bahan kimia sesuai prosedur.

\section{DAFTAR PUSTAKA}

Adhiwijaya, A. (2017). "Pelaksanaan Pencegahan dan Pengendalian Infeksi Dalam Peningkatan Mutu Pelayanan di Rumah Sakit Umum Daerah Labuang Baji Makassar". Fakultas Keperawatan. Universitas Hasanuddin. Makassar.

Arifianto. (2017). “Kepatuhan Perawat Dalam Menerapkan Sasaran Keselamatan Pasien Pada Pengurangan Risiko Infeksi Dengan Penggunaan Alat Pelindung Diri di RS. Roemani Muhammadiyah Semarang”. Fakultas Kedokteran. Universitas Diponegoro. Makassar.

Dianasari, T \& Koesyanto, H. (2017). Penerapan Manajemen Keselamatan Radiasi di Instalasi Radiologi Rumah Sakit. Unnes Journal of Public Health, 6(3), 2584-7604.

Estri, A.B., Putri, I. M., dkk. (2019). Penngendalian dan Pencegahan Infeksi(PPI). Yogyakarta: Unisa.

Indragiri, S \& Yuttya, T. (2018). Manajemen Risiko K3 Menggunakan Hazard Identification Risk Assesment And Risk Control (HIRARC). Jurnal Kesehatan, Vol. 9 No.1.

Madjid, T., Wibowo, A. (2017). Analisis Penerapan Program Pencegahan dan Pengendalian Infeksi di Ruang Rawat Inap RSUD Tebet Tahun 2017. Jurnal Arsi, Vol. 4 No.1. 
Mantiri, E. Z. R. A, Pinontoan, O. R, dkk. (2020). Faktor Psikologi dan Perilaku Dengan Penerapan Manajemen Keselamatan dan Kesehatan Kerja Rumah Sakit. Journal of Public Health and Community Medicine. Vol. 1 No.3.

Putri, O. Z. (2017). Analisis Risiko Keselamatan dan Kesehatan Kerja Pada Petugas Kesehatan Instalasi Gawat Darurat Rumah Sakit Akademik UGM. Jurnal Kesehatan, 10(1), 1979-7621.

Salawati, Liza. (2012.). Pengendalian Infeksi Nosokomial di Ruang Intensive Care Unit Rumah Sakit. Jurnal Kedokteran Syiah Kuala. Volume 12 No. 1.

Simamora, R. H. (2019). Pengaruh Penyuluhan Identifikasi Pasien dengan Menggunakan Media Audiovisual terhadap Pengetahuan Pasien Rawat Inap. Jurnal Keperawatan Silampari, 3(1), 342-351.

Simamora, R. H. (2020). Learning of Patient Identification in Patient Safety Programs Through Clinical Preceptor Models. Medico Legal Update, 20(3), 553-556.

Syahidah, H.N. \& Musfiroh, I. (2018). Review: Aspek Keamanan dan Keselamatan Kerja Dalam Produksi Sediaan Farmasi. Farmaka,Volume 16 No. 1. 